\title{
Time Dependent Influence of Aerobic Heterotrophic Bacteria - Cyanobacteria Interaction during Biodegradation of Poly Aromatic Hydrocarbons
}

\section{Ichor $\mathrm{T}^{*}$, Gberikon GM and Terwase Jerry}

Department of Biological Sciences, University of Agriculture, Makurdi, Nigeria

\begin{abstract}
Biodegradation of polyaromatic hydrocarbons (PAHs) by aerobic heterotrophic bacteria, cyanobacteria, consortium of cyanobacteria and aerobic heterotrophic bacteria and the control was monitored for a period of 49 days, using GC-MS. The chromatograms showed that after contamination of water with same volume of crude in same quantity of water for all the treatments, PAHs were; 3.68, 23.5, 13.7 and $5.49 \mathrm{mg} / \mathrm{L}$ for $\mathrm{AHB}, \mathrm{CB}, \mathrm{AHB}+\mathrm{CB}$ and control. The PAHs components were naphthalene, acencephthylene, acenaphthene, fluorence, anthracence, phenanthrene, fluoranthene, pyrene, beiz @ anthracene, chrysene, benzo ( $h$ ) fluoranthene, benzo $(k)$ fluoranthene, benzo (a) pyrene, dibenzo $(a, h)$ anthracene, indeno $(1,2,3-c, d)$ perylene, benzo $(g, h, i)$ perylene. The result showed a decrease in the quantity of PAHs for all the treatment options on the last day of the experiment though some fluctuations in the quantity of PAHs' were observed in all the treatment options throughout the period monitored. The growth of AHB and cyanobacteria however increased steadily with time throughout the sampling period of the experiment in all the treatment options. The degradation of PAH's was statistically significant $(p<0.05)$ with time.
\end{abstract}

Keywords: Polycyclic aromatic hydrocarbon; Cyanobacteria; Consortium; Bodo creek

\section{Introduction}

Polycyclic aromatic hydrocarbons (PAHs) are a group of organic compounds which contain carbon and hydrogen with the carbon arranged in a series of adjoining six member benzene rings and is present in water, crude oil and tars [1]. They can have a range of substituents such as alkyl, nitro, and amino groups in their structure (Nitrogen, sulfur, and oxygen atoms can also be incorporated into their ring system. The precursors for PAHs present in crude oil reportedly include natural products, such as steroids, which have been transformed through chemical conversion to aromatic hydrocarbons over time. They are known to be recalcitrant and are not easily degradable. They are considered hazardous because of their potential trophic biomagnifications and acute toxicity. The behavior of PAHs in the natural environment is of great environmental concern because of their toxic, mutagenic, and carcinogenic characteristics and how they adversely affect both abiotic and biotic processes such as volatilization, photooxidation, chemical oxidation, bioaccumulation and microbial transformation. The role of microorganisms play in the environment through breakdown, mineralization and biodegradation of organic compounds in nature has been reported to be the most effective means of PAH removal from the natural environment [2-6].

Biodegradability of Poly-aromatic hydrocarbons (PAHs) is generally related to the number of fused benzene rings [7]. Half-lives in soil and sediment of the three ring Phenanthrene molecule may range from 16 to 126 days while for the five-ring benzo (a) Pyrene they may range from 299 to more than 1400 days [8]. The persistence of higher molecular weight PAHs is due largely to their low water solubility and resonance energy of their structures [9].

Sediminicola has been reportedly found in the chronically oil and PAH contaminated Liaodong Bay of Bohai Sea, China [10]. Previous studies on PAHs degradation in marine environments implicated Cycloclasticus as a major PAH degrader during oil spills [11-16]. Marinobacter has also been reported to have degraded alkane and PAH whereas Flavobacterium was implicated PAH degradation $[17,18]$. Newton reported that in one sample set which was collected while oil was visibly washing ashore from Orange Beach in June, OTUs related to Marinobacter were reported to have largely increased in the community. Naphthalene, the simplest form of PAHs has been observed previously to be the most readily degraded PAH. Bacteria initially oxidized it by incorporating both atoms of molecular oxygen into the aromatic molecule to form cis-1,2-dihydroxy naphthalene. Salicyalmehyde and pyruvate and produced through ring cleavage of 1,2 - dihydroxy naphthalene. The aldehyde is then oxidized to salicylate that is subsequently converted to catechol which is further oxidized via the ortho or Meta pathway as per described earlier for benzene. In naphthalene degradation by the themophilic Bacillus thermoleovorans, mesophilic microorganisms might have a different pathway for Polyaromatic degradation compared to mesophiles. Pseudomonas has been reported to degrade naphthalene in experimental systems and is thought to be involved in the co-metabolization of fluorene [19]. Annweiller reported intermediates such as 2,3-dihydroxy naphthalene; 2-carboxynnarmic acid and phthalic and benzoic acid were identified in addition to typical metabolites of naphthalene degradation known from mesophiles in the pathway of B. thermoleovorans. Thalassospira is also implicated in degradation of fluorene and naphthalene and was found to be associated with oil on water surface during the DWH blowout previously by Liu and Liu $[20,21]$.

Sphingomonas, Mycobacterium, Pseudomonas, and Burkholderia; and consortiums of bacteria such as Pseudomonas with Flavobacterium reportedly degraded benzo[a]pyrene [22]. Within a mixed culture of Flavobacterium sp. and Pseudomonas sp., the degradation of benzo[a]

"Corresponding author: Ichor Tersagh, Department of Biological Sciences University of Agriculture, Makurdi, Nigeria, Tel: +234(0)7039256061; E-mail: smartichor@uam.edu.ng

Received May 02, 2016; Accepted June 01, 2016; Published June 09, 2016

Citation: Ichor T, Gberikon GM, Jerry T (2016) Time Dependent Influence of Aerobic Heterotrophic Bacteria - Cyanobacteria Interaction during Biodegradation of Poly Aromatic Hydrocarbons. J Pet Environ Biotechnol 7: 286. doi: 10.4172/2157 7463.1000286

Copyright: (c) 2016 Ichor T, et al. This is an open-access article distributed under the terms of the Creative Commons Attribution License, which permits unrestricted use, distribution, and reproduction in any medium, provided the original author and source are credited. 
pyrene was also reported [18]. The utilization of fluoranthane, a HMW PAH, as a sole source of carbon and energy is possible in a seven-member bacteria consortium [23]. Pyrene was also reportedly metabolized by a variety of bacteria through different pathways for the different bacteria $[24,25]$. Catabolism of a PAH molecule as reported by previous research findings started initially by the oxidation of $\mathrm{PAH}$ to a dihydrodiol using a multicomponent enzyme system. The dihydroxylated intermediates produced could then be processed through an ortho cleavage or a meta cleavage pathway, leading to the production of intermediates such as protocacechuates and catechols which can be converted to tricarboxylic acid cycle intermediates.

Marine cyanobacteria have been reported in previous literatures to have oxidized aromatic hydrocarbons under photoautotrophic growth conditions. The genera of Cyanobacterial reported in previous studies to have degraded hydrocarbons under aerobic conditions include; Aphanocapsa, Anabaena, Microcoleus, Nostoc, Oscillatoria and Phormidium [26]. Microcoleus chthonoplastes and Phormidium corium cultures were observed to have degraded n-alkanes [27]. Oscillatoria sp. and Agmenellum quadruplicatum had oxidized naphthalene to 1-naphthol $[28,29]$. Oscillatoria sp. strain JCM oxidized biphenyl to 4-hydroxybiphenyl and A. quadruplicatum had previously been reported to have metabolized phenanthrene into trans-9, 10-dihydroxy-9, 10dihydro-phenanthrene and 1-methoxyphenanthrene as reported by Narro [24,30]. Several other strains were reported from earlier research findings to have degraded crude oil and other complex organic compounds such as surfactants and herbicides [31-34].

This research was however prompted by previous research findings on the capability of resident microbial flora to biodegrade petroleum hydrocarbons and the controversy that generated about the specific roles played by each of aerobic heterotrophic bacteria and cyanobacteria in the consortium during petroleum hydrocarbon degradation since microbial mats appear at almost every site of oil pollution and whether cyanobacteria possess the capability for biodegradation of petroleum hydrocarbons. In the present study, we monitored biodegradation of PAHs in brackish surface water of petroleum hydrocarbon contaminated Bodo creek by indigenous aerobic heterotrophic bacteria, cyanobacteria and the consortium as the main aim of the study. The objectives were:

A. Monitor the biodegradation of poly aromatic hydrocarbons by aerobic heterotrophic bacteria, cyanobacteria and the aerobic heterotrophic bacteria - cyanobacteria consortium.

B. Identify key bacterial and cyanobacteria resident populations in Bodo creek involved in poly aromatic hydrocarbon degradation using conventional culturing and molecular methods.

C. Determine the Phylogenetic relationship of the consortium of aerobic heterotrophic bacteria - cyanobacteria.

\section{Materials and Methods}

The study area is oil contaminated water body, Bodo creek located in Ogoni land in Gokana, LGA of Rivers State, in Niger Delta region.

\section{Media and incubation conditions}

BG-11 medium consisting (g/liter) of $\mathrm{NaNO}_{3}(1.5), \mathrm{K}_{2} \mathrm{HPO}_{4}(0.004)$, $\mathrm{MgSO}_{4} \cdot 7 \mathrm{H}_{2} \mathrm{O}$ (0.0075), $\mathrm{CaCl}_{2} \cdot 2 \mathrm{H}_{2} \mathrm{O}(0.036), \mathrm{Na}_{2} \mathrm{CO}_{3}$ (0.02), citric acid $(0.006)$, ferric ammonium citrate $(0.006)$, disodium magnesium EDTA (0.001) and trace metal solution $1.0 \mathrm{~mL} /$ liter comprising of $\mathrm{H}_{3} \mathrm{BO}_{3}, \mathrm{MnCl}_{2} .4 \mathrm{H}_{2} \mathrm{O}, \mathrm{Co}\left(\mathrm{NO}_{3}\right)_{2} \cdot 6 \mathrm{H}_{2} \mathrm{O}, \mathrm{ZnSO}_{4} \cdot 7 \mathrm{H}_{2} \mathrm{O}, \mathrm{Na}_{2} \mathrm{MO}_{4} \cdot 2 \mathrm{H}_{2} \mathrm{O}$,
$\mathrm{CuSO}_{4} \cdot 5 \mathrm{H}_{2} \mathrm{O}$ was prepared for the growth of cyanobacteria and adjusted to a $\mathrm{pH}$ of 7.4. The medium was prepared according to the methods of Ichor and Salleh $[35,36]$.

\section{Enumeration of cyanobacteria}

Cyanobacteria were enumerated as described by Ichor [35]. Ten brackish water and sediment samples collected from crude oil contaminated Bodo creek in Rivers State were taken to Environmental Microbiology Laboratory of University of Portharcourt and analyzed. The water samples were shaken to suspend the sediment. $1 \mathrm{~mL}$ of the raw water sample was then removed and diluted into $99 \mathrm{~mL}$ of sterile distilled water which was serially diluted and $1 \mathrm{~mL}$ removed from the third dilution and plated on BG-11 medium which had been solidified using agar agar that was treated with ciprofloxacin and nystatin in duplicate plates. $1 \mathrm{~g}$ of the soil sediment samples were dissolved in $9 \mathrm{~mL}$ of distilled water and filtered using Whatman No. 1 filter paper. The filterate was serially diluted and same procedure followed as described for water. An aliquot of cyanobacteria culture was prepared using different medium- water volume ratio of 90: 10, 80: 20, 70:30, 60: 40 and 50: $50 \mathrm{~mL}$ and vice-versa and incubated in a cotton wool corked Erlenmeyer flask for 14 days and exposed to natural sunlight for 12 $\mathrm{hr}$ and darkness for $12 \mathrm{hr}$ under ambient temperature as described by Ichor [35]. The set up were monitored and shaken twice daily to ensure uniform distribution and avoid sedimentation of the nutrients from the BG-11 medium.

\section{Preparation of inoculum and biodegradation experiment}

Aerobic heterotrophic bacteria aliquot was prepared by transferring a loopful of $24 \mathrm{hr}$ culture of each isolate into $400 \mathrm{~mL}$ of sterile nutrient broth in $500 \mathrm{~mL}$ Erlenmeyer flask and incubated for $24 \mathrm{hrs}$.

A bloom culture of cyanobacterial aliquot using BG II medium formulations was also prepared by transterring $1 \mathrm{~mL}$ of each viable culture in to $400 \mathrm{~mL}$ of the medium and incubated for $48 \mathrm{hrs}$ under natural sunlight for $12 \mathrm{hr}$ and darkness for $12 \mathrm{hr}$.

Treatment options of brackish water samples labeled AHB and $\mathrm{CB}$ were prepared by asceptically transferring $200 \mathrm{~mL}$ each of aerobic heterotrophic bacteria and cyanobacteria aliquot into $500 \mathrm{~mL}$ of sterile distilled water in two separate $1000 \mathrm{~mL}$ flask respectively. AHB + CB was prepared by transferring $200 \mathrm{~mL}$ each of aerobic heterotrophic bacteria and cyanobacteria aliquot into another $500 \mathrm{~mL}$ of sterile distilled water in $1000 \mathrm{~mL}$ flask. Each option was standardized using 0.5 M Macfarland solution [37]. The inoculum size used for each treatment option was $100 \mathrm{~mL}$ of standardized aliquot. The water containers for the experimental set up were each filled with 11 litres of water and labeled $\mathrm{AHB}, \mathrm{CB}, \mathrm{AHB}+\mathrm{CB}$ and $\mathrm{C}$ for the control and contaminated with $32300 \mathrm{ppm}$ of sterile Bony light crude oil sample obtained from shell petroleum development company. Water samples $\mathrm{AHB}, \mathrm{CB}, \mathrm{AHB}+$ $\mathrm{CB}$ were inoculated with aerobic heterotrophic bacteria, cyanobacteria and aerobic heterotrophic bacteria + cyanobacteria respectively while the control was left uninoculated. Sample CB was treated with $0.25 \mathrm{mg} /$ $\mathrm{mL}$ of ciprofloxacin and nystatin, $\mathrm{AHB}$ was treated with $\mathrm{CuSO}_{4}$ and nystatin to prevent cyanobacteria and fungal activities in the setup, $\mathrm{AHB}+\mathrm{CB}$ was treated with only $0.25 \mathrm{mg} / \mathrm{mL}$ of nystatin while the control was left untreated. The containers for the treatments were washed with detergents and rinsed severally with distilled water prior to the experimental set up [37].

\section{Molecular analysis of bacterial and cyanobacterial isolates}

DNA extraction, polymerase chain reaction: Gene sequencing 
Citation: Ichor T, Gberikon GM, Jerry T (2016) Time Dependent Influence of Aerobic Heterotrophic Bacteria - Cyanobacteria Interaction during Biodegradation of Poly Aromatic Hydrocarbons. J Pet Environ Biotechnol 7: 286. doi: 10.4172/2157-7463.1000286

and analysis for bacterial isolates used was done as reported by Ichor [37]. Universal primers CYA 106F (CGC ACG GGT GAG TAA CGC GTG A and CYA 359F(GGG GAA TYT TCC GCA ATG GG) with a 40 nucleotide GC clamp ( $5^{1}$ CGC CCG CCG CGC CCC GCG CCG GTC CCG CCG CCC CCG CCC G $3^{1}$ ) on the $5^{1}$ end forward primer and CYA 781R (equimolar mixture of CYA781Ra (GAC TAC TGG GGT ATC TAA TCC CAT T) and CYA 781Rb (GAC TAC AGG GGT ATC TAA TCC CTT T) reverse primers for amplification of a segment of cyanobacterial 16SrRNA gene (70) were synthesized. A semi nested PCR reaction was carried out with the first reaction using primers CYA $106 \mathrm{~F}$ and CYA 781R and followed by a reaction with primers CYA $359 \mathrm{~F}$ and CYA781R. the PCR was carried out in a $25 \mu \mathrm{L}$ final volume of reaction mixture containing $100 \mathrm{ng}$ of DNA $2.5 \mu \mathrm{L}$ of 10x PCR buffer with $200 \mu \mathrm{g}$ bovine serum albumin (nuclease free) and $0.2 \mathrm{u}$ Taq DNA polymerase (Banngalore Genei, India) in a 1 cycler (BioRad, USA). The thermal cycling profile was thus; initial denaturation for 3 mins at $94^{\circ} \mathrm{C}$ followed by 35 amplification cycles each consisting of $1.5 \mathrm{~min}$ denaturation at $94^{\circ} \mathrm{C}, 1 \mathrm{~min}$ annealing at $59^{\circ} \mathrm{C}$ and a 2 min elongation at $72^{\circ} \mathrm{C}$ with a final 5 min elongation at $72^{\circ} \mathrm{C}$ [35].

Sequences obtained were compared with known sequences in the Gen Bank using the basic local alignment search tool (BLAST) of the National Centre for Biotechnology Information (NCBI). Species were identified based on the percentage similarity with known sequences in the data base [35].

\section{Results}

Biodegradation of polyaromatic hydrocarbons (PAHs) by aerobic heterotrophic bacteria, cyanobacteria, consortium of cyanobacteria and aerobic heterotrophic bacteria and the control was monitored for a period of 49 days, using GC-MS. The chromatograms showed that after contamination of water with same volume of crude in same quantity of water for all the treatments, PAHs were; 3.68, 23.5, 13.7 and $5.49 \mathrm{mg} / \mathrm{L}$ for $\mathrm{AHB}, \mathrm{CB}, \mathrm{AHB}+\mathrm{CB}$ and control. The PAHs components were naphthalene, acencephthylene, acenaphthene, fluorence, anthracence, phenanthrene, fluoranthene, pyrene, beiz @ anthracene, chrysene, benzoth) fluoranthene, benzo (k) fluoranthene, benzo (a) pyrene, dibenzo $(\mathrm{a}, \mathrm{h})$ anthracene, indeno $(1,2,3-\mathrm{C}, \mathrm{d})$ perylene, benzo $(\mathrm{g}, \mathrm{h}, \mathrm{i})$ perylene. The result showed a decrease in the quantity of PAHs for all the treatment options on the last day of the experiment though some fluctuations in the quantity of PAHs' were observed. For instance, on day 14, PAH's reduced to $1.66 \mathrm{mg} / \mathrm{L}$ but rose again to $2.79 \mathrm{mg} / \mathrm{L}$ on day 42 for AHB, $0.99 \mathrm{mg} / \mathrm{L}$ in week 2 (14 days) to 1.26 in week 3 (21 days) force $0.13 \mathrm{mg} / \mathrm{L}$ in week 4 (28 days) to $1.79 \mathrm{mg} / \mathrm{L}$ in week 6 (42 days) for AHBC $+\mathrm{CB}$ and $0.79 \mathrm{mg} / \mathrm{L}$ for week 5 ( 35 days) to $0.85 \mathrm{mg} / \mathrm{L}$ in week 6 (42 days) for control. This trend was observed in all the treatment options. Figure 1 shows the degradation of PAH's by the various treatment options introduced with time. Though with some observed fluctuations in the degradation of PAH's the growth of AHB and cyanobacteria steadily increased with time throughout the sampling period of the experiment in all the treatment options (Figures 1-5). The result from the chromatogram revealed complete degradation of naphthalene in week (3) (21 days) for all the treatments though it had the highest concentration during the first day of sampling in all the treatment. Dibenzo $(\mathrm{a} \mathrm{h})$ anthracene disappeared on week 4 for treatment $\mathrm{AHB}+\mathrm{CB}$; ideno $(1,2,3-\mathrm{c}, \mathrm{d})$ perylene and Benzo (g, $h, i)$ perylene were completely degraded from week 6 from the same treatment. In treatment CB, Dibenzo $(\mathrm{a}, \mathrm{h})$ anthracene, ideno $(1,2,3$, $\mathrm{c}, \mathrm{d})$ perylene and Benzo $(\mathrm{g}, \mathrm{h}, \mathrm{i})$ perylene were completely degraded by week 5. Complete degradation of same PAHs components occurred in week 4 for the control. This trend was not observed in AHB though fluoranthene and pyrene were completely degraded in week 3 and week 5 respectively. Acenaphtylene fluctuated throughout the period monitored in all the treatments but disappeared after week 7 for the control. This pattern of fluctuation was observed in Acenaphthene, fluorene, anthracene, phenanthrene, Benz (a) anthrcene, chrysene, Benz (k) fluoranthene, Benz (a) pyrene, dibenzo ( $a, h$ ) anthracene and benzo $(\mathrm{g}, \mathrm{h})$ perylene for all the treatment including the control. The fluctuation is probably due to novel synthesis where a complex compound could have broken down to release other PAHs components which were previously lost. Biodegradation of components of PAHs was statistically significant $(\mathrm{p}<0.05)$ with time for sample AHB, CB, C and $\mathrm{AHB}+\mathrm{CB}$ (Figure 6).

\section{Discussion}

Biodegradation of polyanomatic hydrocarbon (PAHs) by the treatment options was also measured using GC-MS. The result

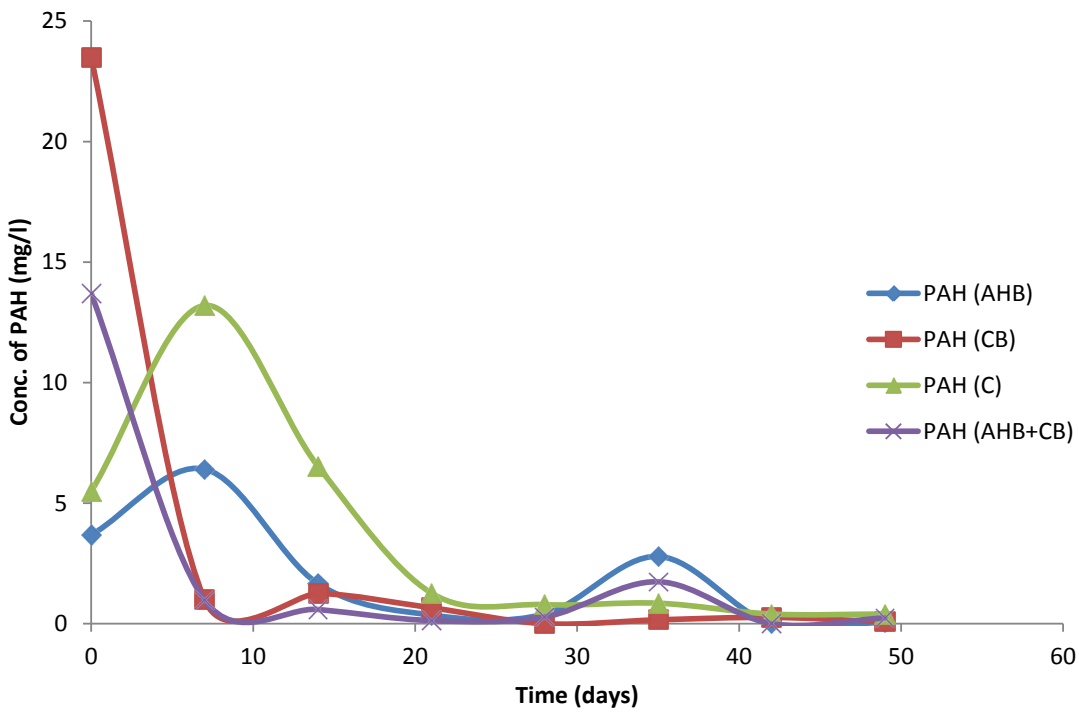

Figure 1: Biodegradation of PAHs by the treatment options. 
Citation: Ichor T, Gberikon GM, Jerry T (2016) Time Dependent Influence of Aerobic Heterotrophic Bacteria - Cyanobacteria Interaction during Biodegradation of Poly Aromatic Hydrocarbons. J Pet Environ Biotechnol 7: 286. doi: 10.4172/2157-7463.1000286

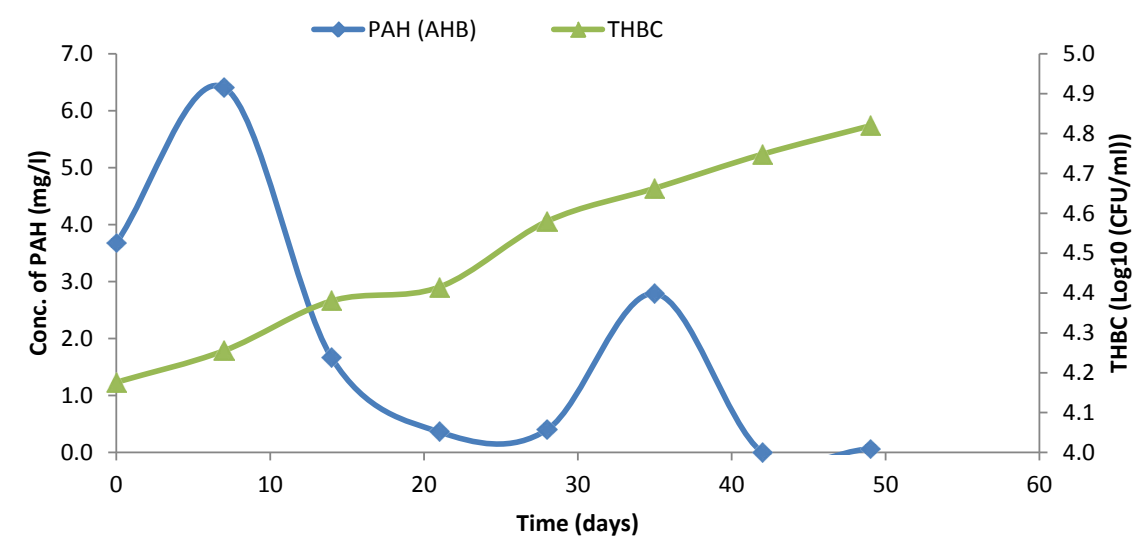

Figure 2: Biodegradation of PAHs by AHB for 49 days.

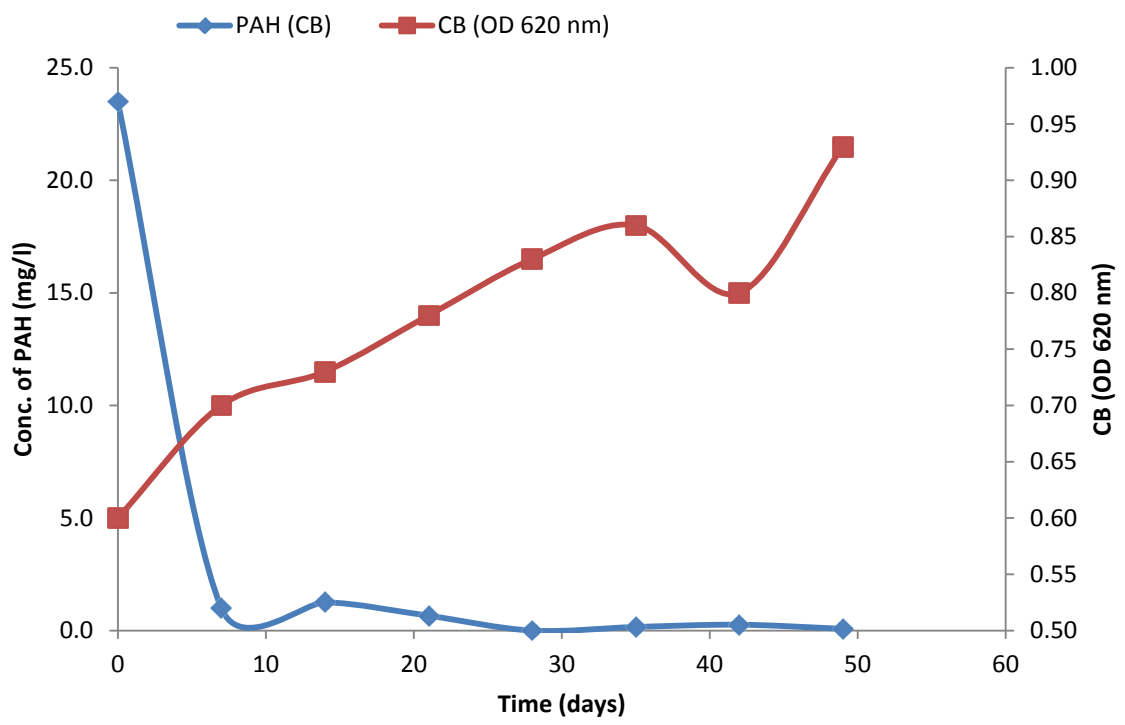

Figure 3: Biodegradation of PAHs by CB for 49 days period.

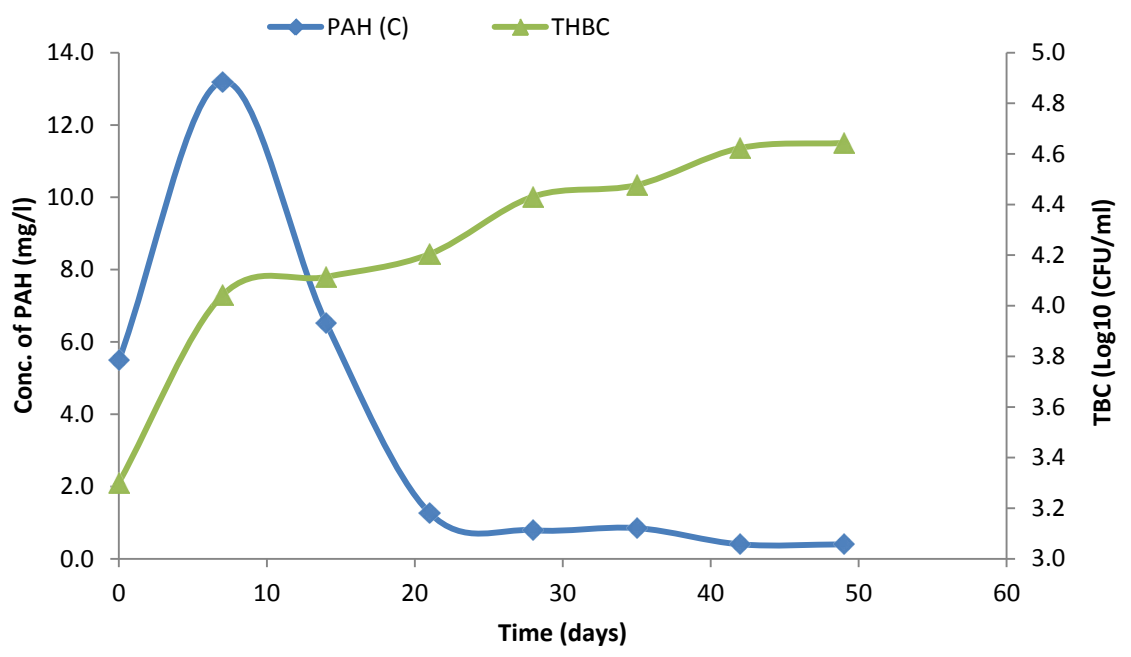

Figure 4: Biodegradation of PAHs in crude oil contaminated control. 
Citation: Ichor T, Gberikon GM, Jerry T (2016) Time Dependent Influence of Aerobic Heterotrophic Bacteria - Cyanobacteria Interaction during Biodegradation of Poly Aromatic Hydrocarbons. J Pet Environ Biotechnol 7: 286. doi: 10.4172/2157-7463.1000286

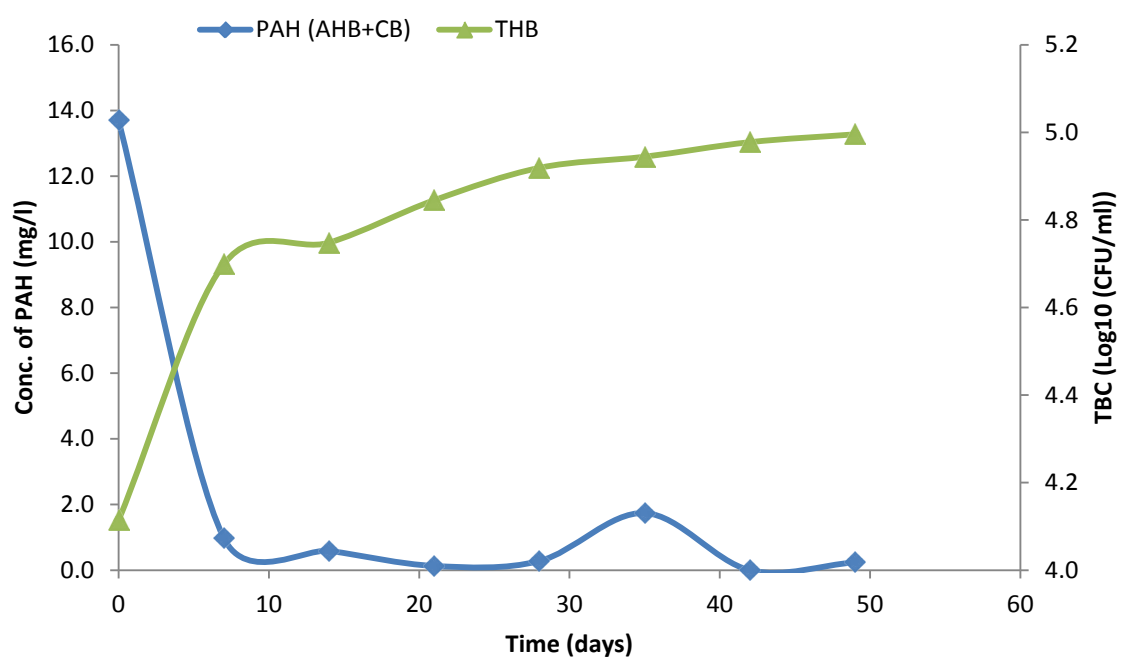

Figure 5: Biodegradation of PAHs by consortium of AHB and CB for 49 days.

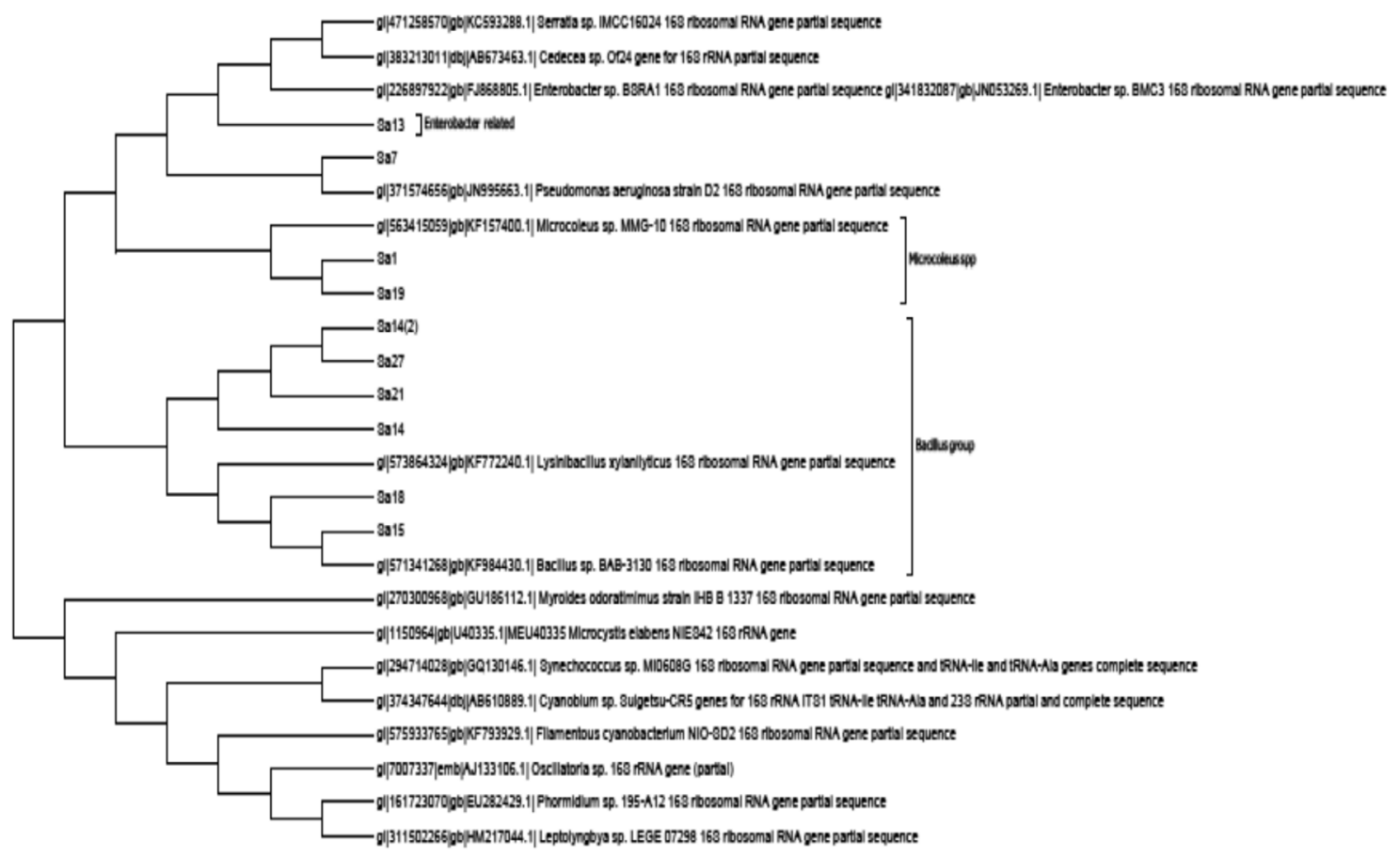

Figure 6: Unrooted phylogenetic tree showing affiliation of bacterial and cyanobacteria consortium based on partial 165 rRNA sequences.

revealed a reduction in the quantity of PAHs in all the treatment options on day 49 though fluctuations in the quantity were observed. For AHB treatment for instance, PAHs rose progressively from 3.68 on day 1 to 6.41 on day 7 and reduced to 1.66 on day 14 . This pattern of fluctuation continued in other treatments though not observed negative impact on growth of microorganisms used in the experiment and the control hence microbial growth increased from day 0 till the last day of the experiment. PAHs are hydrophobic and naturally carcinogenic in marine organism and pose serious health concern to heath of both aquatic life and humans through bioaccumulation [3840]. It is established that they cause cancers, mutagenic and teratogenic conditions in plants, lower animals and this will definitely get into man in the food web of repeated chances of eaten and being eaten.
Earlier reports have shown that microbial activity has the most significant influence in PAH's removal from the environment [4-6]. The metabolic pathways and genetics of degradation of low molecular PAHs such as naphthalene, phenanthrene and anthracene by gramnegative bacteria has been the focus of research in recent times [41]. Arulazhagan reported that a consortain of bacterial utilized $3 \mathrm{mg} / \mathrm{L}$ of naphthalene as sole carbon source and nearly $98 \%$ of it degraded in four days by bacteria [1]. The result for this study as revealed by GC-MS chromatograms, complete degradation of naphthalene was observed on day 21 from day 1 of the experimental set up in all the treatments including cyanobacteria treatment option. Earlier degradation of naphthalene may be due to its relative solubility in water and high vapour pressure, which biodegradation and volatilization in open 
Citation: Ichor T, Gberikon GM, Jerry T (2016) Time Dependent Influence of Aerobic Heterotrophic Bacteria - Cyanobacteria Interaction during Biodegradation of Poly Aromatic Hydrocarbons. J Pet Environ Biotechnol 7: 286. doi: 10.4172/2157-7463.1000286

water is known to affect its fate in aquatic ecosystems. Fluorene has been listed as a priority pollutant by EPA. Gomes was as previously reported was utilized by a consortium of bacteria as the sole source of carbon and showed a maximum degradation of $99 \%$, anthracene 95\%, phenanthrene and fluorene $97-98 \%$ the result showed that the consortium of bacterial degraded PAHs almost completely in (95\%) in four days [1,42]. Naphthalene, phenanthrene and authracene which are classified as low molecular mass PAHs were degraded in this present study and the result shows that Dibenzo $(\mathrm{a}, \mathrm{h})$ anthracene was completely degraded in 21 days by $\mathrm{AHB}+\mathrm{CB}$, Ideno $(1,2,3-\mathrm{c}, \mathrm{d})$ perylene and Benzo $(\mathrm{g}, \mathrm{h}, \mathrm{i})$ perylene completely degraded on day 42 by the same treatment.

Cyanobanteria (CB) apart from degrading naphthalene, degraded dibenzo $(\mathrm{a}, \mathrm{h})$ anthranaene, ideno $(1,2,3-\mathrm{c}, \mathrm{d})$ penylene and Benzo ( $g, h, i)$ perylene completely by day 28 . Similar pattern of degradation occurred in the control day 21. For AHB treatment, however, fluoranthene completely degraded on day 14 , pyrene on day 28 , phananthrene on day 42, Acenaphthylene, dibenz $(\mathrm{a}, \mathrm{h})$ anthrancene, ideno (1, 2, 3-c, d) diperylene, Benzo (g, h, i) perylene and dizenz ( $a, h$, ) anthracene completely degraded on day 49 . There were disappearance and reappearnce in the course of the experiment for some PAHs on some days monitored. Our result shows biodegradation of PAHs by both acrobic heterotrophic bacteria and cyanobacteria which completely disagrees with the report of Abed and Abed and Koster that cyanobacteria only plays an indirect role in oil biodegration by providing the associated aerobic heterotrophs with oxygen needed for the breakdown of aliphatic and aromatic hydrocarbons, fixed nitrogen and simple organics [43-45]. In this study apart from naphthalene which was degraded by day 14 by all the treatments, all the other components of PAHs were degraded much earlier by $\mathrm{AHB}+\mathrm{CB}, \mathrm{CB}$ and control compared to AHB. This implies that cyanobacteria exerts to a greater extent an influence on biodegradative activities of the consortium in biodegradation and its presence responsible for earlier degradation of the components of PAHs including in the control which was not cured of any specific microorganism. It is apparent that PAHs cannot be oxidized effectively by one single organism as mixed cultures are seen to outperform single species isolated from a consortium [12]. A dominant benzo (a) pyreme degrading bacteria obtained from a marine enrichment which contained three strains Cochrabactrum, Stenotrophomonas and Pseudomonas) degraded PAHs faster than when tested individually [46]. Pelz reported the biodegradation of 4-chlorosalicylate by combination of Pseudomonas MT1 [47], Pseudomonas MT4 and Achromobacter MT 4 using a ${ }^{13} \mathrm{C}$-labelled substrates. Strain MT 1 degraded 4-chlorosalicylate and provided carbon seletons for the other strains which degraded the toxic metabolites that could have inhibited MT1 if it was allowed to accumulate. One of the toxic intermediates was taken (4-chlorocatechol) up by strain MT3 and further degraded. Mueller reported that cyanobacteria could play important role in the degradation and transformation PAHS since they are widely distributed in aquatic environment [48]. They reported on its ability to oxidize PAHs under photoautotrophic conditions to form hydroxylated intermediates. Naphthalene and phenathrene according to Narro et al. oxidized to form metabolites, Oscillatoria sp strain JCM oxidized naphthalene and Agmellum quadruplicatum PR6 metabolized phenathrene to trans-9, 10-dehychoxy-9, 10-dihydrophenanthrene and 1-methoxy phenanthrene and Benzo (a) pyrene to form a metabolite Isomeric cis-dihydrodiols which is suggestive of dioxygenase catalyzed reaction [49].

\section{Conclusion}

The present study showed significant degradation of petroleum hydrocarbons by the cyanobacteira isolates and varied from previous reports by [44,50-54]. Degradation of components of PAHs was observed throughout the 49 days period of the experiment. The degradation of PAHs was significant with time at $\mathrm{p}<0.05$. However, the PAH's level was minimal. Polycyclic aromatic hydrocarbons are reported to be of minimal values in an environment without previous history of crude contamination, and very high in polluted environment that has undergone fire burning. The age of contamination/pollution, the higher the PAH's concentration. In this our investigation, the spiking of crude oil in uncontaminated surface water was a recent effort which could have accounted for low level of PAH's in the contaminated water [55-57].

\section{References}

1. Arulazhagan $P$, Vasudevan N, Yeom N (2010) Biodegradation of polycyclic aromatic hydrocarbon by a halotolerant bacterial consortium isolated from marine environment. International Journal of Environmental sciences and Technology 7: 639-652.

2. Cerniglia CE (1993) Biodegradation of polycyclic aromatic hydrocarbons. Cur Opin Biotech 3: 331-338

3. Nwuche CO, Ugoji EO (2008) Effects of heavy metal pollution on the soil microbial activity. Int J Environ Sci Tech 5: 409-414.

4. Haghighat S, Sepahy A, Assadi, M, Pasdar H (2008) Ability of indigenous Bacillus licheniformis and Bacillus subtilis in microbial enhanced oil recovery. Int J Environ Sci Tech 5: 385-390

5. Agbozu IE, Opuene K (2009) Occurrence and Diagenetic Evolution of Perylene in the Sediments of Oginigba Creek, Southern Nigeria. Int J Environ Res 3 : 117-120.

6. Atlas R, Bragg J (2009) Bioremediation of marine oil spills: when and when not-the Exxon Valdez experience.. Microb Biotechnol 2: 213-221.

7. Cerniglia CE, Heitkamp MA (1989) Microbial degradation of polycyclic aromatic hydrocarbons (PAH) in the aquatic environment. In metabolism of polycyclic aromatic hydrocarbon in the aquatic environment. $U$ Varanasi (ed.), CRC Press, Florida. pp: 41-68.

8. Shuttleworth KL, Cerniglia CE (1995) Environmental aspects of PAH biodegradation. Appl Biochem Biotechnol 54: 291-302.

9. Cerniglia CE (1992) Biodegradation of polycyclic aromatic hydrocarbons Biodegradation 3: 351-368

10. Zheng B, Wang L, Liu L (2014) Bacterial community structure and its regulating factors in the intertidal sediment along the Liaodong Bay of Bohai Sea, China. Microbiol Res 169: 585-592.

11. Kasai Y, Kishira H, Harayama S (2002) Bacteria belonging to the genus Cycloclasticus play a primary role in the degradation of aromatic hydrocarbons released in a marine environment. Appl Environ Microbiol 68: 5625-5633.

12. Wang J, Xu H, An M, Yan G (2008) Kinetics and characteristics of phenanthrene degradation by a microbial consortium. Petrol. Sci. 5: 73-78.

13. Jurelevicius D, Alvarez VM, Marques JM, De Sousa Lima LR, Dias Fde A et al. (2013) Bacterial community response to petroleum hydrocarbon amendments in freshwater, marine, and hypersaline water-containing microcosms. App Environ Microbiol 79: 5927-5935.

14. Hazen TC, Dubinsky EA, DeSantis TZ, Andersen GL, Piceno YM, et al. (2010) Deep-sea oil plume enriches indigenous oil-degrading bacteria. Science 330 204-208.

15. Chakraborty R, Borglin SE, Dubinsky EA, Andersen GL, Hazen TC (2012) Microbial response to the MC-252 oil and corexit 9500 in the Gulf of Mexico. Front Microbiol 3: 357

16. Mason OU, Hazen TC, Borglin S, Chain PSG, Dubinsky EA, et al. (2012 Metagenome, metatranscriptome and single-cell sequencing reveal microbia response to Deep water Horizon oil spill. ISME J. 6: 1715-1727.

17. Vila J, Nieto JM, Mertens J, Springael D, Grifoll M (2010) Microbial community structure of a heavy fuel oil-degrading marine consortium: linking microbia dynamics with polycyclic aromatic hydrocarbon utilization. FEMS Microbiol. Ecol. 73: 349-362. 
Citation: Ichor T, Gberikon GM, Jerry T (2016) Time Dependent Influence of Aerobic Heterotrophic Bacteria - Cyanobacteria Interaction during Biodegradation of Poly Aromatic Hydrocarbons. J Pet Environ Biotechnol 7: 286. doi: 10.4172/2157-7463.1000286

18. Trzesicka-Mlynarz D, Ward OP (1995) Degradation of polycyclic aromatic hydrocarbons (PAHs) by a mixed culture and its component pure cultures obtained from PAH-contaminated soil. Can J Microbiol 41: 470-476.

19. Stringfellow WT, Aitken MD (1995) Competitive metabolism of naphthalene, methylnaphthalenes, and fluorene by phenanthrene-degrading pseudomonads. Appl Environ Microbiol 61: 357-362.

20. Kodama Y, Stiknowati LI, Ueki A, Ueki K, Watanabe K (2008) Thalassospira tepidiphila sp. nov., a polycyclic aromatic hydrocarbon-degrading bacterium isolated from seawater. Int J Syst Evol Microbiol 58: 711-715.

21. Liu Z, Liu J (2013) Evaluating bacterial community structures in oil collected from the sea surface and sediment in the northern Gulf of Mexico after the Deepwater Horizon oil spill. Microbiologyopen 2: 492-504.

22. Juhasz AL, Naidu R (2000) Bioremediation of high molecular weight polycyclic aromatic hydrocarbons: a review of the microbial degradation of benzo[a] pyrene. Int Biodeterior Biodegradation 45: 57-88.

23. Mueller JG, Chapman PJ, Pritchard PH (1989) Action of a flueorantheneutilizing bacterial community on plycyclic aromatic hydrocarbon components of creosote. Applied and Environmental Microbiology 55: 3085-3090.

24. Narro ML, Cerniglia CE, Van Baalen C, Gibson DT (1992) Metabolism of phenanthrene by the marine cyanobacterium Agmenellum quadruplicatum PR6. Appl Environ Microbiol 58: 1351-1359.

25. Weissenfels WD, Beyer M, Klein J, Rehm HJ (1991) Microbial metabolism of fluranthene: Isolation and identification of ring fission products. Applied and Microbiology and Biotechnology 34: 528-535.

26. Prince RC (1993) Petroleum spill bioremediation in marine environments. Crit Rev Microbiol 19: 217-242.

27. Radwan SS, Al-Hasan RH (2001) Potential application of coastal biofilm-coated gravel particles for treating oily waste. Aquatic Microbial Ecology 23:113-117.

28. Cerniglia CE, Gibson DT, Van Baalen C (1979) Algal oxidation of aromatic hydrocarbons: formation of 1-naphthol from naphthalene by Agmenellum quadruplicatum, strain PR-6. Biochem Biophys Res Commun 88: 50-58.

29. Cerniglia CE, Gibson DT, Baalen CV (1980a) Oxidation of naphthalene by cyanobacteria and microalgae. Journal of General Microbiology 116:495-500.

30. Cerniglia CE, Van Baalen C, Gibson DT (1980) Oxidation of biphenyl by the cyanobacterium, Oscillatoria sp., strain JCM. Arch Microbiol 125: 203-207.

31. Yan GA, Jiang JW, Wu G, Yan X (1998) Disappearance of linear alkylbenzene sulfonate from different cultures with Anabaena sp. HB 1017. Bull Environ Contam Toxicol 60: 329-334.

32. Radwan SS, Al-Hasan RH (2000) Oil pollution and cyanobacteria. In: Whitton, BA Potts M (ed.) The Ecology of Cyanobacteria. Kluwer, The Netherlands, pp.307-319.

33. Raghukumar C, Vipparty V, David JJ, Chandramohan D (2001) Degradation of crude oil by marine cyanobacteria. Appl Microbiol Biotechnol 57: 433-436.

34. Mansy AE, El-Bestway E (2002) Toxicity and biodegradation of fluometuron by selected cyanobacterial species. World Journal of Microbiology and Biotechnology 18: 125-131.

35. Ichor T, Okerentugba PO, Okpokwasili GC (2016) Biodegradation of total petroleum hydrocarbon by a consortium of cyanobacteria isolated from crude oil polluted brackish waters of bodo creeks in Ogoniland, Rivers State. Research Journal of Environmental Toxicology 10: 16-27.

36. Salleh AB, Ghazali MF, Zaliha NR, Basri M (2003) Bioremediation of petroleum hydrocarbon pollution. Indian Journal of Biotechnology 2: 411-425.

37. Ichor T, Okerentugba PO, Okpokwasili GC (2014) Biodegradation of total petroleum hydrocarbon by aerobic heterotrophic bacteria isolated from crude oil contaminated brackish waters of bodo creek. Journal of Bioremediation and Biodegradation 5: 236 .

38. Yu SH, Ke L, Wong YS, Tam NF (2005) Degradation of polycyclic aromatic hydrocarbons by a bacterial consortium enriched from mangrove sediments. Environ Int 31: 149-154.
39. Perugini M, Visciano P, Giammarino A, Manera M, Di Nardo W, et al. (2007) Polycyclic aromatic hydrocarbons in marine organisms from the Adriatic Sea, Italy. Chemosphere 66: 1904-1910.

40. Lee KH, Byeon SH (2010) The biological monitoring of urinary 1hydroxypyrene by PAH exposure among smokers. Int J Environ Res 4: 439-442.

41. Williams PA, Sayers JR (1994) The evolution of pathways for aromatic hydrocarbon oxidation in Pseudomonas. Biodegradation 5: 195-217.

42. Gomes RCB, Nogueira R, Oliveira JM, Peixoto J, Brito AG (2006) Kinetics of fluorene biodegradation by a mixed culture. Proceedings of the second IASTED International Conference Advanced Technology in the Environmental Field. Lanzarote, Canary Island, Spain. 84-87.

43. Abed RM, Safi NM, Köster J, de Beer D, El-Nahhal Y, et al. (2002) Microbia diversity of a heavily polluted microbial mat and its community changes following degradation of petroleum compounds. Appl Environ Microbiol 68: 1674-1683.

44. Abed RMM (2010) Interaction between cyanobacteria and aerobic heterotrophic bacteria in the degradation of hydrocarbons. International Biodeterioration and Biodegradation 64: 58-64.

45. Abed RMM, Koster J (2005) The direct role of aerobic heterotrophic bacteria associated with cyanobacteria in the degradation of oil compounds. International Biodeterioration \& Biodegradation 55: 29-37.

46. Luo YR, Tian Y, Huang X, Yan CL, Hong HS, et al. (2009) Analysis of community structure of a microbial consortium capable of degrading benzo(a) pyrene by DGGE. Mar Pollut Bull 58: 1159-1163.

47. Pelz O, Tesar M, Wittich RM, Moore ERB, Timmis KN, et al. (1999) Towards elucidation of microbial community metabolic pathways: unravelling the network of carbon sharing in a pollutant-degrading bacterial consortium by immunocapture and isotopic ratio mass spectrometry. Environmental Microbiology 1: 167-174.

48. Mueller JG, Cerniglia CE, Pritchard PH (1996) Bioremediation of environments contaminated by polycyclic aromatic hydrocarbons. In: Bioremediation: Principles and application, Cambridge University press, Cambridge pp.125194.

49. Warshawsky D, Ladow K, Schneider J (2007) Enhanced degradation of benzo[a]pyrene by Mycobacterium sp. in conjunction with green alga. Chemosphere 69: 500-506.

50. Cohen Y (2002) Bioremediation of oil by marine microbial mats. Int Microbio 5: 189-193.

51. De Oteyza TG, Grimalt JO, Diestra E, Sole A, Esteve I (2004) Changes in the composition of polar and apolar crude oil fractions under the action of Microcoleus consortia. Applied Microbiology and Biotechnoiogy 66: 226-232.

52. Benthian M, Wieland A, de Oteyza T, Grimalt J, Kühl M (2004) Oil-contamination effects on a hypersaline microbial mat community (Camargue, France) as studied with microsensors and geochemical analysis. Ophelia 58: 135-150.

53. Abed RM, Al-Thukair A, de Beer D (2006) Bacterial diversity of a cyanobacterial mat degrading petroleum compounds at elevated salinities and temperatures. FEMS Microbiol Ecol 57: 290-301.

54. Chaillan F, Gugger M, Saliot A, Couté A, Oudot J (2006) Role of cyanobacteria in the biodegradation of crude oil by a tropical cyanobacterial mat. Chemosphere 62: 1574-1582.

55. Al-Hassan RH, Al-Bader DA, Sorkhoh NA, Radwan SS (1998) Evidence for n-Alkane consumption and oxidation by filamentous cyanobacteria from oilcontaminated coasts of the arabian gulf. Marine Biology 130: 521-527.

56. Keck J, Ronald CS, Coover M, Park K, Symons B (1989) Evidence for cooxidation of polynuclear atomic hydrocarbons in soil. Water Research. 23:1467-1476.

57. Kelley I, Freeman JP, Evans FE, Cerniglia CE (1993) Identification of metabolites from the degradation of fluoranthene by Mycobacterium sp. strain PYR-1. Appl Environ Microbiol 59: 800-806. 